\title{
Heart Failure and a Plant-Based Diet. A Case-Report and Literature Review
}

\author{
Kathleen E. Allen ${ }^{1}$, Divya Gumber ${ }^{2}$ and Robert J. Ostfeld ${ }^{2 \star}$ \\ ${ }^{1}$ Department of Food and Nutrition, NewYork-Presbyterian, New York, NY, United States, ${ }^{2}$ Division of Cardiology, Montefiore \\ Health System, Bronx, NY, United States
}

A 54-year-old female with grade 3 obesity body mass index (BMl $45.2 \mathrm{~kg} / \mathrm{m}^{2}$ ) and type II diabetes (hemoglobin A1c 8.1\%) presented to her primary care physician in May 2017 with a chief complaint of left lower extremity edema. Work-up revealed heart failure with depressed left ventricular systolic function. Upon diagnosis, she substantially altered her lifestyle, changing her diet from a "healthy western" one to a whole food plant-based one. Guideline directed medical therapy for heart failure was also utilized. Over five and a half months, she lost $22.7 \mathrm{~kg}$ and reversed her diabetes without the use of diabetes medications. Her left ventricular systolic function normalized. Although causality cannot be determined, this case highlights the potential role of a plant-based diet in helping to reverse heart failure with reduced ejection fraction. This article will review how a minimally processed whole food plant-based dietary pattern and similar dietary patterns, such as

OPEN ACCESS

Edited by:

Hana Kahleova,

Physicians Committee for Responsible Medicine, United States

Reviewed by:

Ertugrul Kilic,

Istanbul Medipol University, Turkey Tianan Alan Jiang, McCormick \& Company, Inc., United States

*Correspondence:

Robert J. Ostfeld rostfeld@montefiore.org

Specialty section: This article was submitted to Clinical Nutrition,

a section of the journal

Frontiers in Nutrition

Received: 15 December 2018 Accepted: 20 May 2019 Published: 11 June 2019

Citation:

Allen KE, Gumber D and Ostfeld RJ (2019) Heart Failure and a Plant-Based Diet. A Case-Report and Literature Review. Front. Nutr. 6:82. doi: 10.3389/fnut.2019.00082 the Dietary Approach to Stop Hypertension diet, may contribute to the reversal of left ventricular dysfunction.

Keywords: diet, heart failure, hypertension, plant-based, vegetarian

\section{CASE}

A 54-year-old female with grade 3 obesity body mass index (BMI $45.2 \mathrm{~kg} / \mathrm{m}^{2}$ ) and type II diabetes (hemoglobin A1c 8.1\%) presented to her primary care physician in May 2017 with a chief complaint of left lower extremity edema. Venous duplex revealed no deep venous thrombosis and an X-Ray revealed lower extremity atherosclerosis with no fracture. She was sent to a cardiologist. Electrocardiogram demonstrated normal sinus rhythm and a left bundle branch block. Echocardiography revealed a left ventricular ejection fraction of $25 \%$ without significant valvular pathology; heart failure was diagnosed. Renal, liver, and thyroid function, as well as ferritin and potassium levels were within normal limits. HIV was non-reactive. She was not anemic. She was started on a beta-blocker, an ACE inhibitor, and a statin. Cardiac MRI in June 2017, revealed a dilated cardiomyopathy and an ejection fraction of $21 \%$. Coronary CT angiogram revealed an Agatston coronary artery calcium score of 458. Extensive calcification on the CT angiogram precluded assessment of coronary artery stenosis. Hence cardiac catheterization was performed and revealed a cardiomyopathy out of proportion to coronary artery disease with a $30 \%$ proximal left anterior descending artery stenosis, a $25 \%$ proximal and a $60 \%$ distal left circumflex artery stenosis, and a $65 \%$ first obtuse marginal artery lesion. The left main and right coronary arteries were without stenosis. She was shaken by her diagnosis and became determined to adopt a more healthful diet. She changed her diet from "healthy western" to whole food plant-based (Table 1). She also started supplemental vitamin B12. She lost $22.7 \mathrm{~kg}$ in $<6$ months, resulting in a BMI of $35.1 \mathrm{~kg} / \mathrm{m}^{2}$. Her diabetes resolved, with her hemoglobin A1c falling to $5.7 \%$ without the use of diabetes medications. Her baseline dyspnea on exertion improved considerably. Repeat echocardiography in November 2017 revealed a normal left ventricular ejection fraction of 55\% (Table 2). 
TABLE 1 | Patient's dietary pattern pre- and post-dietary change.

\begin{tabular}{|c|c|}
\hline "Healthy western" diet & Plant-based diet (daily) \\
\hline $\begin{array}{l}\text { - } \text { Chicken (without the skin) } \\
\text { - Fish } \\
\text { - Turkey } \\
\text { - Eggs } \\
\text { - Lean cuts of red meat } \\
\text { - Small amounts of } \\
\text { processed red meat } \\
\text { - Diet soft drinks } \\
\text { - Processed foods (e.g., } \\
\text { chips and cakes) } \\
\text { - } 1-2 \text { servings of } \\
\text { vegetables or fruits daily }\end{array}$ & $\begin{array}{l}\text { - No animal products } \\
\text { - At least } 3 \text { servings dark leafy greens } \\
\text { - At least } 3 \text { servings of vegetables } \\
\text { - At least } 3 \text { servings of fruit } \\
\text { - } 1-3 \text { servings of beans/legumes } \\
\text { - } 1-3 \text { servings of whole grains } \\
\text { - } 1 \text { Tablespoon herb/spice } \\
\text { - } 1 \text { serving of raw unsalted nuts or seeds } \\
\text { - } 2 \text { Tablespoons of hemp seeds/chia seeds } \\
\text { - } \text { - Around flax meal } \\
\text { - Limit packaged/processed foods }\end{array}$ \\
\hline
\end{tabular}

Regarding the plant-based diet, patients are not given caloric or macronutrient goals and are invited to consume freely within these parameters.

TABLE 2 | Health parameters at baseline and after five and a half months on a plant-based diet.

\begin{tabular}{lcc}
\hline Parameter & Baseline & After $\mathbf{5} \frac{1 / 2}{\mathbf{2}}$ months \\
\hline BMl & $45.2 \mathrm{~kg} / \mathrm{m}^{2}$ & $35.1 \mathrm{~kg} / \mathrm{m}^{2}$ \\
Hemoglobin A1c & $8.1 \%$ & $5.7 \%$ \\
Ejection fraction & $25 \%$ & $55 \%$ \\
\hline
\end{tabular}

Although causality cannot be determined, this case highlights the potential role of a plant-based diet in helping to reverse systolic dysfunction, or heart failure with reduced ejection fraction.

This article will review how a minimally processed whole food plant-based dietary pattern and similar dietary patterns, such as the Dietary Approach to Stop Hypertension (DASH) diet and vegetarian diet, may contribute to the reversal of left ventricular dysfunction. For the purposes of this case report and literature review, the term plant-based diet will include dietary patterns that are exclusively plant-based and dietary patterns that are predominantly plant-based, such as the DASH diet and vegetarian dietary patterns.

\section{BACKGROUND}

Heart failure (HF) is a condition in which the heart is unable to provide adequate blood flow to meet the normal metabolic needs of the body and can occur with either a reduced or a preserved left ventricular ejection fraction (1). HF is a leading cause of morbidity and mortality with a prevalence of more than 5.5 million in the US and 23 million globally (2). Each year in the US, over 550,000 individuals are newly diagnosed with HF (3)-about half die within 5 years (1).

Numerous risk factors for the development and progression of $\mathrm{HF}$ are influenced by diet, including inflammation, hypertension,

Abbreviations: BMI, Body mass index; DASH, Dietary Approach to Stop Hypertension; HDL, High density lipoprotein; HF, Heart Failure; HFpEF, heart failure with preserved ejection fraction; HTN, Hypertension; LDL, Low-density lipoprotein; PBD, Plant-based Diet. dysbiotic microbiome, hyperlipidemia, obesity, and diabetes (4-6). However, the medical community has traditionally focused on pharmacotherapy and devices and not on nutrition in both the primary and secondary prevention of $\operatorname{HF}(7,8)$.

This focus may occur because cardiologists receive little instruction on either nutrition or nutrition counseling $(9,10)$. In a recent survey of more than 900 cardiologists, although $95 \%$ believed that their role should include counseling patients about nutrition, 90\% received minimal or no related training (10). This training deficit is not unique to cardiology and extends to most fields, including internal medicine and obstetrics/ gynecology $(9,11,12)$.

This deficit may represent a preventive opportunity lost throughout the lifecycle. The Barker Hypothesis suggests that the intrauterine environment influences cardiovascular health later in life $(13,14)$. In human and animal models, the presence of maternal obesity adversely impacted cardiac morphology and metabolism, predisposing offspring to cardiovascular disease $(15,16)$. Offspring of maternal pigs fed a high fat, highcalorie diet versus a standard diet have numerous structural and metabolic cardiac derangements that may put them at risk for HF (16). Human mothers consuming more meat and fish had offspring with elevated cortisol levels which may predispose to hypertension and the metabolic syndrome (17). Consequently, more healthful diets may provide both primordial prevention, and prevention throughout the lifecycle (18).

\section{PROSPECTIVE COHORT STUDIES}

Prospective cohort studies support the beneficial impact of plantbased dietary patterns on incident HF (19-23). In a study of 38,075 Finnish people over a median of 14.1 years, higher consumption of vegetables was associated with a lower incidence of HF in men, but not in women (21). Similarly, among 20,900 healthy male physicians in the Physicians' Health Study I, greater consumption of fruits and vegetables was associated with a decreased risk of HF (19). A subset of the Reasons for Geographic and Racial Differences in Stroke (REGARDS) Cohort of 15,569 persons with no Coronary Artery Disease or HF diagnosis was divided into five dietary patterns: Alcohol/Salads, Convenience, Plant-based, Southern, and Sweets. After a median follow-up of more than 7 years, patients with closer adherence to the Plantbased dietary pattern had lower risk of incident HF (23). In a prospective cohort from Sweden of 34,319 women without cardiovascular disease and cancer at initial assessment, after 12.9 years, greater fruit and vegetable consumption was associated with a lower rate of HF (22).

\section{THE INFLUENCE OF DIET ON HEART FAILURE RISK FACTORS}

\section{Inflammation}

Elevated serum levels of inflammation increase risk factors for $\mathrm{HF}$, as well as incident $\operatorname{HF}(24,25)$. Plant-based diets (PBD) decrease serum levels of inflammation (26-29) and may be 
protective (5). This protective effect is in part mediated through Reactive Oxygen Species (ROS) or free radicals $(30,31)$.

ROS are unstable molecules that promote inflammation and may react with and damage myocardial cells leading to interstitial fibrosis, myocyte hypertrophy, and decreased myocardial contractility (32). PBDs with high levels of antioxidants and other bioactive compounds may be protective by reducing levels of ROS whereas animal-based diets with lower levels of antioxidants, may not $(30,33)$. In addition, the consumption of animal foods may facilitate ROS creation via heme iron (34) and other pro-inflammatory compounds such as NGlycolylneuraminic acid (Neu5gc) (35), Advanced Glycation End-Products (AGEs) (36), trimethylamine amine (TMAO) (37), and nitrates utilized to preserve processed meats (38), thereby potentially further inducing myocardial dysfunction and $\operatorname{HF}(23,24)$.

Moreover, vegetarian versus omnivorous diets are associated with lower plasma levels of the pro-oxidant compound, myeloperoxidase, which promotes atherosclerotic plaque formation, and progression. This promotion may lead to atherosclerotic plaque rupture, myocardial infarction, and HF (39).

\section{Hypertension}

Hypertension (HTN) is a common precursor to HF, increasing its risk by $2-3$ fold $(40,41)$. Accordingly, in the Framingham cohort, a blood pressure (BP) of $\geq 160 / 100$ vs. $<140 / 90$ doubled the lifetime risk of incident $\mathrm{HF}$ (40). PBDs and predominantly PBDs, such as the DASH or vegetarian diet, may lower both systolic and diastolic BP (42-44), via a number of mechanisms, including favorably modifying the renin-angiotensin (45) and sympathetic nervous systems (46), greater potassium and decreased sodium consumption (47), improved blood vessel dilation (44, 46, 48), and changes in baroreceptors (46).

In prospective studies, red meat and poultry increased incident HTN (49) whereas plant proteins lowered it (50). In the Chicago Western Electric Study, greater consumption of fruits or vegetables was associated with significantly lower BP whereas beef, lamb, poultry, and veal consumption was associated with higher BP after 7 years (51). Similarly, in a large cohort from China of over 450,000 subjects, greater consumption of fresh fruit was associated with decreased systolic BP by $4 \mathrm{mmHg}$ (52). The Diet Approach to Stop Hypertension (DASH) diet, which is low in animal products, total, and saturated fat and high in fruits and vegetables, reduced both systolic and diastolic BP by 5.5 and $3.0 \mathrm{mmHg}$, respectively, in hypertensive patients (53). Correspondingly, large prospective studies reported that greater adherence to a DASH diet was associated with a 22 and $37 \%$ decreased HF risk in men and women, respectively $(54,55)$. A PBD, however, may even further lower BP. A vegan diet has been associated with achieving a lower BP than omnivorous, pescatarian, and vegetarian diets (56).

\section{Microbiome}

The gut microbiome consists of around one hundred trillion microorganisms and impacts our immunologic, cardiovascular, and overall health (57). For example, the pro-atherogenic compound, Trimethylamine N-oxide (TMAO) is formed, in part, via the interplay of the gut microbiome with the nutrients L-carnitine and choline (58). Increasing TMAO levels are associated with increasing severity of HF, rates of MI, and overall mortality (58-64). Accordingly, TMAO may induce vascular inflammation, increase platelet reactivity (58), and reduce reverse cholesterol transport (4). A PBD rapidly selects for a different microbiome than does an animal-based diet and hence produces less TMAO than does an animal-based diet (4) possibly accounting, in part, for the fewer cardiovascular events seen in those consuming a minimally processed plant-based diet $(58,65)$.

Furthermore, soluble dietary fiber, found exclusively in plantbased foods (66), nourishes healthful bacteria in the colon enabling them to produce short-chain fatty acids (67). Shortchain fatty acids then nourish the enterocyte (68) which may lead to reduced cholesterol biosynthesis by the enterocyte by down-regulating the enterocyte's expression of genes involved in cholesterol biosynthesis, and thereby lower serum cholesterol levels (69). As elevated serum cholesterol is a key cause of coronary artery disease and myocardial infarction (70-73), and hence HF, plant-based nutrition may further lower HF risk by impacting cholesterol biosynthesis in the enterocyte $(4,69)$.

\section{Hyperlipidemia}

Plant-based diets lower serum lipid levels in part due to their soluble fiber, phytosterols, low saturated fat content, absence of cholesterol, and potentially due to their ability to reduce enterocyte cholesterol biosynthesis $(69,74,75)$. Moreover, a PBD improves lipids levels specifically in patients with decreased left ventricular ejection fraction $(76,77)$. Conversely, animal-based diets are associated with increased serum cholesterol levels (78).

Furthermore, a PBD may render low-density lipoprotein (LDL) cholesterol particles less prone to oxidation (74, 79-81). Oxidized LDL particles are particularly atherogenic, damaging to endothelial cells, and promoting of inflammation and oxidative stress $(82,83)$.

While high-density lipoprotein (HDL) levels may decrease on a PBD (43), recent studies have suggested that increasing HDL levels may not be beneficial and may be harmful (84). In addition, it appears that a healthful lifestyle may render an HDL particle protective, while an unhealthful one renders it atherogenic (85). Accordingly, HDL efflux capacity, or its ability to perform reverse cholesterol transport, irrespective of the absolute HDL serum level, may be a more important measure of its potential beneficial health impact $(43,84,86)$. Thus, aspects of a PBD, such as pistachios and almonds, may improve HDL efflux capacity $(86,87)$.

\section{Obesity}

Obesity is a risk factor for HF and may account for approximately 11 and 14 percent of HF cases in men and women, respectively. Increases in BMI are linearly associated with an increase in HF risk, where those with obesity having twice the risk of HF compared to those with a healthy BMI (88). Similarly, in the Multi-Ethnic Study of Atherosclerosis (MESA) cohort, greater self-reported weight at 20 and 40 years of age was associated with increased HF risk later in life (89). 
This increased risk may occur as obesity is associated with altered left ventricular remodeling (90). Furthermore, obesity may promote risk factors for HF, such as inflammation, HTN, dyslipidemia, DM, and sleep apnea (88, 91-93).

PBDs have been associated with greater weight loss $(94,95)$, decreased weight gain (96), and lower BMIs $(97,98)$ when compared with other dietary patterns. Conversely, greater intake of animal-based foods is correlated with a higher BMI $(97,98)$. Accordingly, a randomized controlled trial found a vegan diet to be associated with significantly greater weight loss $(-7.5 \%)$ than a pesco-vegetarian, semi-vegetarian, or omnivorous diet $(-3.2$, -3.2 , and $-3.1 \%$, respectively) over the course of 6 months (94). A prospective cohort study found each $250 \mathrm{~g} / \mathrm{d}$ increase in meat (red meat, processed meat, and poultry) consumption to be associated with an increase in weight of $2 \mathrm{~kg}$ over 5 years (99). In the Seventh-Day Adventist study, mean BMI increased as diet became more animal-centric: $23.6 \mathrm{~kg} / \mathrm{m}^{2}$ in vegans, $25.7 \mathrm{~kg} / \mathrm{m}^{2}$ in lacto-ovo-vegetarian, $26.3 \mathrm{~kg} / \mathrm{m}^{2}$ in pesco-vegetarians, 27.3 $\mathrm{kg} / \mathrm{m}^{2}$ in semi-vegetarians, and $28.8 \mathrm{~kg} / \mathrm{m}^{2}$ in non-vegetarians (98). PBDs likely contribute to the obtention and maintenance of a healthy weight through their high fiber content, low caloric density, and potentially, their ability to augment resting energy expenditure (100).

\section{Diabetes}

Diabetes Mellitus (DM) is associated with an approximate $400 \%$ increase in the incidence of $\mathrm{HF}$ (101) and poorly controlled diabetes is associated with worse HF outcomes. Each $1 \%$ increase in hemoglobin A1c (HbA1c) was associated with a $12 \%$ increase in HF hospitalizations after controlling for other HF risk factors (102). Similarly, insulin resistance, often a precursor for diabetes, is associated with an increased risk of incident HF (103).

A PBD results in a lower incidence of diabetes (104, $105)$ and hemoglobin A1c levels $(106,107)$ and may reduce insulin requirements despite a lack of weight loss (108). As such, a PBD may improve HF incidence and outcomes (101, 102). As aforementioned, PBDs are associated with decreased inflammation (26-29), which may ameliorate diabetes by improving both insulin sensitivity and beta cell function (109, 110). Moreover, PBDs are low in saturated fat, which upon accumulation in muscle and hepatic cells, contributes to insulin resistance $(100,111,112)$.

Accordingly, in the Seventh-Day Adventist Study, the relationship between Type 2 diabetes and degree of dietary plant consumption appeared to lie on a continuum, with a prevalence of: $2.9 \%$ in vegans, $3.2 \%$ in lacto-ovo vegetarians, $4.8 \%$ in pesco-vegetarian, $6.1 \%$ in semi-vegetarians, and $7.6 \%$ in non-vegetarians (98).

\section{REFERENCES}

1. Inamdar AA, Inamdar AC. Heart failure: diagnosis, management and utilization. J Clin Med. (2016) 5:62. doi: 10.3390/jcm5070062

2. Bui AL, Horwich TB, Fonarow GC. Epidemiology and risk profile of heart failure. Nat Rev Cardiol. (2011) 8:30-41. doi: 10.1038/nrcardio.2010.165

\section{HEART FAILURE WITH PRESERVED EJECTION FRACTION}

Heart failure with preserved ejection fraction (HFpEF), or diastolic heart failure, is common and has similar symptoms and adverse outcomes as heart failure with reduced ejection fraction (113). It is hypothesized that HFpEF may be secondary, in part, to diffuse endothelial dysfunction, including that of the myocardial microvasculature, due partly, to increased inflammation (113). Many plant-based foods are anti-inflammatory (26), and increase Nitric Oxide bioavailability (114), thereby improving vascular health and potentially ameliorating this microvascular dysfunction $(24,113,115)$. A PBD may also prevent or treat numerous comorbid conditions, such as obesity, HTN, kidney disease, and diabetes (44, 98, 104-107, 116-118), potentially providing additional preventive and therapeutic benefit. The Dietary Approach to Stop Hypertension in "Diastolic" Heart Failure (DASH-DHF) pilot study evaluated the impact of a DASH diet on 13 post-menopausal women with diastolic HF. After 3 weeks, consuming the DASH diet was associated with significant improvements in blood pressure, arterial elasticity, and oxidative stress (115).

\section{CONCLUSION}

Our patient's improvements were temporally associated with her adoption of a whole food plant-based diet. Plant-based diets are associated with improvements in risk factors for heart failure and with direct benefits on cardiac metabolism and function. Given the burden of heart failure, its adverse prognosis, and the overall evidence to date, a plant-based diet should be considered as part of a multifaceted approach to heart failure care.

\section{ETHICS STATEMENT}

Full name of the ethics committee: The Montefiore Einstein Institutional Review Board.

Consent Procedure: Written informed consent was obtained from the patient to publish her identifiable/case report data.

\section{AUTHOR CONTRIBUTIONS}

RO identified the case and had sole access to patient information. $\mathrm{RO}, \mathrm{KA}$, and DG all performed background research, and contributed both to the writing and editing of the paper.

\section{FUNDING}

RO also received a research grant from Purjes Foundation.

3. Hunt SA, Abraham WT, Chin MH, Feldman Arthur M, Francis Gary S, Ganiats Theodore G, et al. 2009 Focused update incorporated into the ACC/AHA 2005 guidelines for the diagnosis and management of heart failure in adults. Circulation. (2009) 119:e391-e479. doi: 10.1161/CIRCULATIONAHA.109. 192065 
4. Koeth RA, Wang Z, Levison BS, Buffa JA, Org E, Sheehy BT, et al. Intestinal microbiota metabolism of L-carnitine, a nutrient in red meat, promotes atherosclerosis. Nat Med. (2013) 19:576-85. doi: 10.1038/nm.3145

5. Kerley CP. A review of plant-based diets to prevent and treat heart failure. CFR. (2018) 4:54-61. doi: 10.15420/cfr.2018:1:1

6. Qi J, You T, Li J, Pan T, Xiang L, Han Y, et al. Circulating trimethylamine Noxide and the risk of cardiovascular diseases: a systematic review and metaanalysis of 11 prospective cohort studies. J Cell Mol Med. (2018) 22:185-94. doi: $10.1111 /$ jcmm.13307

7. Sciatti E, Lombardi C, Ravera A, Vizzardi E, Bonadei I, Carubelli V, et al. Nutritional deficiency in patients with heart failure. Nutrients. (2016) 8:442. doi: 10.3390/nu8070442

8. Fiuzat M, Mayne ST, Hillebrenner M, Stockbridge N, Zuckerman B, Califf RM. JACC: heart failure series: FDA in the 21st century: focus on nutrition and heart failure prevention. JACC Heart Fail. (2017) 5:229-31. doi: 10.1016/j.jchf.2016.12.012

9. Devries S, Dalen JE, Eisenberg DM, Maizes V, Ornish D, Prasad A, et al. A deficiency of nutrition education in medical training. Am J Med. (2014) 127:804-6. doi: 10.1016/j.amjmed.2014.04.003

10. Devries S, Agatston A, Aggarwal M, Aspry KE, Esselstyn CB, Kris-Etherton $\mathrm{P}$, et al. A deficiency of nutrition education and practice in cardiology. Am J Med. (2017) 130:1298-305. doi: 10.1016/j.amjmed.2017.04.043

11. Vetter ML, Herring SJ, Sood M, Shah NR, Kalet AL. What do resident physicians know about nutrition? An evaluation of attitudes, selfperceived proficiency and knowledge J Am Coll Nutr. (2008) 27:287-98. doi: 10.1080/07315724.2008.10719702

12. Antognoli EL, Seeholzer EL, Gullett H, Jackson B, Smith S, Flocke SA. Primary care resident training for obesity, nutrition, and physical activity counseling: a mixed-methods study. Health Promot Pract. (2017) 18:672-80. doi: $10.1177 / 1524839916658025$

13. Barker DJ. Fetal origins of coronary heart disease. BMJ. (1995) 311:171-4. doi: 10.1136/bmj.311.6998.171

14. Harding J. The nutritional basis of the fetal origins of adult disease. Int $J$ Epidemiol. (2001) 30:15-23. doi: 10.1093/ije/30.1.15

15. Blackmore HL, Niu Y, Fernandez-Twinn DS, Tarry-Adkins JL, Giussani DA, Ozanne SE. Maternal diet-induced obesity programs cardiovascular dysfunction in adult male mouse offspring independent of current body weight. Endocrinology. (2014) 155:3970-80. doi: 10.1210/en.2014-1383

16. Guzzardi MA, Liistro T, Gargani L, Ait Ali L, D'angelo G, Rocchiccioli S, et al. Maternal obesity and cardiac development in the offspring: study in human neonates and minipigs. JACC Cardiovasc Imaging. (2017) 11:1750-5. doi: 10.1016/j.jcmg.2017.08.024

17. Reynolds RM, Godfrey KM, Barker M, Osmond C, Phillips DIW. Stress responsiveness in adult life: influence of mother's diet in late pregnancy. $J$ Clin Endocrinol Metab. (2007) 92:2208-10. doi: 10.1210/jc.2007-0071

18. Craig WJ, Mangels AR. Position of the American Dietetic Association: vegetarian diets. J Am Diet Assoc. (2009) 109:1266-82.

19. Djousse L, Driver JA, Gaziano JM. Relation between modifiable lifestyle factors and lifetime risk of heart failure. JAMA. (2009) 302:394-400. doi: 10.1001/jama.2009.1062

20. Pfister R, Sharp SJ, Luben R, Wareham NJ, Khaw KT. Plasma vitamin C predicts incident heart failure in men and women in European Prospective Investigation into Cancer and Nutrition-Norfolk prospective study. Am Heart J. (2011) 162:246-53. doi: 10.1016/j.ahj.2011.05.007

21. Wang Y, Tuomilehto J, Jousilahti P, Antikainen R, Mahonen M, Katzmarzyk PT, et al. Lifestyle factors in relation to heart failure among Finnish men and women. Circ Heart Fail. (2011) 4:607-12. doi: 10.1161/circheartfailure.111.962589

22. Rautiainen S, Levitan EB, Mittleman MA, Wolk A. Fruit and vegetable intake and rate of heart failure: a population-based prospective cohort of women. Eur J Heart Fail. (2015) 17:20-6. doi: 10.1002/ejhf.191

23. Lara KM, Levitan EB, Gutierrez OM, Shikany JM, Safford MM, Judd SE, et al. Dietary patterns and incident heart failure in U.S. Adults without known coronary disease. J Am Coll Cardiol. (2019) 73:2036-45. doi: 10.1016/j.jacc.2019.01.067

24. Anker SD, Von Haehling S. Inflammatory mediators in chronic heart failure: an overview. Heart. (2004) 90:464-70. doi: 10.1136/hrt.2002.007005

25. Kalogeropoulos A, Georgiopoulou V, Psaty BM, Rodondi N, Smith AL, Harrison DG, et al. Inflammatory markers and incident heart failure risk in older adults: the health $\mathrm{ABC}$ (Health, aging, and body Composition) study. $J$ Am Coll Cardiol. (2010) 55:2129-37. doi: 10.1016/j.jacc.2009.12.045

26. Watzl B. Anti-inflammatory effects of plant-based foods and of their constituents. Int J Vitam Nutr Res. (2008) 78:293-8. doi: 10.1024/0300-9831.78.6.293

27. Turner-Mcgrievy GM, Wirth MD, Shivappa N, Wingard EE, Fayad R, Wilcox S, et al. Randomization to plant-based dietary approaches leads to larger short-term improvements in dietary inflammatory index scores and macronutrient intake compared with diets that contain meat. Nutr Res. (2015) 35:97-106. doi: 10.1016/j.nutres.2014.11.007

28. Eichelmann F, Schwingshackl L, Fedirko V, Aleksandrova K. Effect of plantbased diets on obesity-related inflammatory profiles: a systematic review and meta-analysis of intervention trials. Obes Rev. (2016) 17:1067-79. doi: 10.1111/obr.12439

29. Najjar RS, Moore CE, Montgomery BD. Consumption of a defined, plantbased diet reduces lipoprotein(a), inflammation, and other atherogenic lipoproteins and particles within 4 weeks. Clin Cardiol. (2018) 41:1062-8. doi: $10.1002 /$ clc. 23027

30. Kim MK, Cho SW, Park YK. Long-term vegetarians have low oxidative stress, body fat, and cholesterol levels. Nutr Res Pract. (2012) 6:155-61. doi: 10.4162/nrp.2012.6.2.155

31. Hecke T, Camp J, Smet S. Oxidation during digestion of meat: interactions with the diet and helicobacter pylori gastritis, and implications on human health. Compr Rev Food Sci Food Saf. (2017) 16:214-33. doi: 10.1111/1541-4337.12248

32. Tsutsui H, Kinugawa S, Matsushima S. Oxidative stress and heart failure. Am J Physiol Heart Circ Physiol. (2011) 301:H2181-H2190. doi: 10.1152/ajpheart.00554.2011

33. Carlsen MH, Halvorsen BL, Holte K, Bohn SK, Dragland S, Sampson L, et al. The total antioxidant content of more than 3100 foods, beverages, spices, herbs and supplements used worldwide. Nutr J. (2010) 9:3. doi: 10.1186/1475-2891-9-3

34. Kitatsuji C, Izumi K, Nambu S, Kurogochi M, Uchida T, Nishimura S-I, et al. Protein oxidation mediated by heme-induced active site conversion specific for heme-regulated transcription factor, iron response regulator. Sci Rep. (2016) 6:18703. doi: 10.1038/srep 1870

35. Samraj AN, Pearce OMT, Läubli H, Crittenden AN, Bergfeld AK, Banda $\mathrm{K}$, et al. A red meat-derived glycan promotes inflammation and cancer progression. Proc Natl Acad Sci USA. (2015) 112:542-7. doi: $10.1073 /$ pnas. 1417508112

36. Uribarri J, Woodruff S, Goodman S, Cai W, Chen XUE, Pyzik R, et al. Advanced glycation end products in foods and a practical guide to their reduction in the diet. J Am Diet Assoc. (2010) 110:911-6.e912. doi: 10.1016/j.jada.2010.03.018

37. Chen ML, Zhu XH, Ran L, Lang HD, Yi L, Mi MT. Trimethylamine-N-oxide induces vascular inflammation by activating the NLRP3 inflammasome through the SIRT3-SOD2-mtROS signaling pathway. J Am Heart Assoc. (2017) 6:e006347. doi: 10.1161/jaha.117.006347

38. Wolk A. Potential health hazards of eating red meat. J Intern Med. (2017) 281:106-22. doi: 10.1111/joim.12543

39. Navarro JA, De Gouveia LA, Rocha-Penha L, Cinegaglia N, Belo V, Castro MM, et al. Reduced levels of potential circulating biomarkers of cardiovascular diseases in apparently healthy vegetarian men. Clin Chim Acta. (2016) 461:110-3. doi: 10.1016/j.cca.2016.08.002

40. Lloyd-Jones DM, Larson MG, Leip EP, Beiser A, D'agostino RB, Kannel WB, et al. Lifetime risk for developing congestive heart failure: the Framingham Heart Study. Circulation. (2002) 106:3068-72. doi: 10.1161/01.CIR.0000039105.49749.6F

41. Messerli FH, Rimoldi SF, Bangalore S. The transition from hypertension to heart failure: contemporary update. JACC Heart Fail. (2017) 5:543-51. doi: 10.1016/j.jchf.2017.04.012

42. Pettersen BJ, Anousheh R, Fan J, Jaceldo-Siegl K, Fraser GE. Vegetarian diets and blood pressure among white subjects: results from the Adventist Health Study-2 (AHS-2). Public Health Nutr. (2012) 15:1909-16. doi: $10.1017 / \mathrm{s} 1368980011003454$

43. Kent L, Morton D, Rankin P, Ward E, Grant R, Gobble J, et al. The effect of a low-fat, plant-based lifestyle intervention (CHIP) on serum HDL levels and the implications for metabolic syndrome status - a cohort study. Nutr Metab. (2013) 10:58. doi: 10.1186/1743-7075-10-58 
44. Yokoyama Y, Nishimura K, Barnard ND, Takegami M, Watanabe M, Sekikawa A, et al. Vegetarian diets and blood pressure: a meta-analysis. JAMA Intern Med. (2014) 174:577-87. doi: 10.1001/jamainternmed.2013.14547

45. Chen Q, Turban S, Miller ER, Appel LJ. The effects of dietary patterns on plasma renin activity: results from the Dietary Approaches to Stop Hypertension trial. J Hum Hypertens. (2012) 26:664-9. doi: 10.1038/jhh.2011.87

46. Suter PM, Sierro C, Vetter W. Nutritional factors in the control of blood pressure and hypertension. Nutr Clin Care. (2002) 5:9-19.

47. Perez V, Chang ET. Sodium-to-potassium ratio and blood pressure, hypertension, and related factors. Adv Nutr. (2014) 5:712-41. doi: 10.3945/an.114.006783

48. Vogel RA, Corretti MC, Plotnick GD. Effect of a single high-fat meal on endothelial function in healthy subjects. Am J Cardiol. (1997) 79:350-4. doi: 10.1016/S0002-9149(96)00760-6

49. Borgi L, Curhan GC, Willett WC, Hu FB, Satija A, Forman JP. Long-term intake of animal flesh and risk of developing hypertension in three prospective cohort studies. J Hypertens. (2015) 33:2231-8. doi: 10.1097/hjh.0000000000000722

50. Wang YF, Yancy WS Jr., Yu D, Champagne C, Appel LJ, Lin PH. The relationship between dietary protein intake and blood pressure: results from the PREMIER study. J Hum Hypertens. (2008) 22:745-54. doi: $10.1038 /$ jhh. 2008.64

51. Miura K, Greenland P, Stamler J, Liu K, Daviglus ML, Nakagawa H. Relation of vegetable, fruit, and meat intake to 7-year blood pressure change in middle-aged men: the Chicago Western Electric Study. Am J Epidemiol. (2004) 159:572-80. doi: 10.1093/aje/kwh085

52. Du H, Li L, Bennett D, Guo Y, Key TJ, Bian Z, et al. Fresh fruit consumption and major cardiovascular disease in China. N Engl J Med. (2016) 374:133243. doi: 10.1056/NEJMoa1501451

53. Appel LJ, Moore TJ, Obarzanek E, Vollmer WM, Svetkey LP, Sacks FM, et al. A clinical trial of the effects of dietary patterns on blood pressure. DASH Collaborative Research Group. N. Engl J Med. (1997) 336:1117-24. doi: 10.1056/nejm199704173361601

54. Levitan EB, Wolk A, Mittleman MA. Consistency with the DASH diet and incidence of heart failure. Arch Intern Med. (2009) 169:851-7. doi: 10.1001/archinternmed.2009.56

55. Levitan EB, Wolk A, Mittleman MA. Relation of consistency with the dietary approaches to stop hypertension diet and incidence of heart failure in men aged 45 to 79 years. Am J Cardiol. (2009) 104:1416-20. doi: 10.1016/j.amjcard.2009.06.061

56. Appleby PN, Davey GK, Key TJ. Hypertension and blood pressure among meat eaters, fish eaters, vegetarians and vegans in EPIC-Oxford. Public Health Nutr. (2002) 5:645-54. doi: 10.1079/phn2002332

57. Valdes AM, Walter J, Segal E, Spector TD. Role of the gut microbiota in nutrition and health. BMJ. (2018) 361:k2179 doi: 10.1136/bmj.k2179

58. Li XS, Obeid S, Klingenberg R, Gencer B, Mach F, Raber L, et al. Gut microbiota-dependent trimethylamine $\mathrm{N}$-oxide in acute coronary syndromes: a prognostic marker for incident cardiovascular events beyond traditional risk factors. Eur Heart J. (2017) 38:814-24. doi: 10.1093/eurheartj/ehw582

59. Tang WHW, Wang Z, Levison BS, Koeth RA, Britt EB, Fu X, et al. Intestinal microbial metabolism of phosphatidylcholine and cardiovascular risk. N Engl J Med. (2013) 368:1575-84. doi: 10.1056/NEJMoa1109400

60. Tang WH, Hazen SL. The contributory role of gut microbiota in cardiovascular disease. J Clin Invest. (2014) 124:4204-11. doi: $10.1172 /$ jci72331

61. Tang WH, Wang Z, Fan Y, Levison B, Hazen JE, Donahue LM, et al. Prognostic value of elevated levels of intestinal microbe-generated metabolite trimethylamine- $\mathrm{N}$-oxide in patients with heart failure: refining the gut hypothesis. J Am Coll Cardiol. (2014) 64:1908-14. doi: 10.1016/j.jacc.2014.02.617

62. Tang WH, Wang Z, Shrestha K, Borowski AG, Wu Y, Troughton RW, et al. Intestinal microbiota-dependent phosphatidylcholine metabolites, diastolic dysfunction, and adverse clinical outcomes in chronic systolic heart failure. $J$ Card Fail. (2015) 21:91-6. doi: 10.1016/j.cardfail.2014.11.006
63. Troseid M, Ueland T, Hov JR, Svardal A, Gregersen I, Dahl CP, et al. Microbiota-dependent metabolite trimethylamine- $\mathrm{N}$-oxide is associated with disease severity and survival of patients with chronic heart failure. $J$ Intern Med. (2015) 277:717-26. doi: 10.1111/joim.12328

64. Suzuki T, Yazaki Y, Voors AA, Jones DJL, Chan DCS, Anker SD, et al. Association with outcomes and response to treatment of trimethylamine Noxide in heart failure (from BIOSTAT-CHF). Eur J Heart Fail. (2018) doi: 10.1002/ejhf.1338. [Epub ahead of print].

65. Satija A, Bhupathiraju SN, Spiegelman D, Chiuve SE, Manson JE, Willett $\mathrm{W}$, et al. Healthful and unhealthful plant-based diets and the risk of coronary heart disease in U.S. Adults. J Am Coll Cardiol. (2017) 70:411-22. doi: $10.1016 /$ j.jacc.2017.05.047

66. Dhingra D, Michael M, Rajput H, Patil RT. Dietary fibre in foods: a review. J Food Sci Technol. (2012) 49:255-66. doi: 10.1007/s13197-011-0365-5

67. Desai MS, Seekatz AM, Koropatkin NM, Kamada N, Hickey CA, Wolter $\mathrm{M}$, et al. A dietary fiber-deprived gut microbiota degrades the colonic mucus barrier and enhances pathogen susceptibility. Cell. (2016) 167:133953.e1321. doi: 10.1016/j.cell.2016.10.043

68. Den Besten G, Van Eunen K, Groen AK, Venema K, Reijngoud D-J, Bakker BM. The role of short-chain fatty acids in the interplay between diet, gut microbiota, and host energy metabolism. J Lipid Res. (2013) 54:2325-40. doi: 10.1194/jlr.R036012

69. Alvaro A, Sola R, Rosales R, Ribalta J, Anguera A, Masana L, et al. Gene expression analysis of a human enterocyte cell line reveals downregulation of cholesterol biosynthesis in response to short-chain fatty acids. IUBMB Life. (2008) 60:757-64. doi: 10.1002/iub.110

70. Jousilahti P, Vartiainen E, Pekkanen J, Tuomilehto J, Sundvall J, Puska P. Serum cholesterol distribution and coronary heart disease risk. Circulation. (1998) 97:1087-94. doi: 10.1161/01.CIR.97.11.1087

71. Werner RM, Pearson TA. LDL-cholesterol: a risk factor for coronary artery disease-from epidemiology to clinical trials. Can J Cardiol. (1998) 14(Suppl. B): $3 b-10 b$.

72. Abdullah SM, Defina LF, Leonard D, Barlow CE, Radford NB, Willis $\mathrm{BL}$, et al. Long-term association of low-density lipoprotein cholesterol with cardiovascular mortality in individuals at low 10-year risk of atherosclerotic cardiovascular disease. Circulation. (2018) 138:2315-25. doi: 10.1161/CIRCULATIONAHA.118.034273

73. Grundy SM, Stone NJ, Bailey AL, Beam C, Birtcher KK, Blumenthal RS, et al. 2018 AHA/ACC/AACVPR/AAPA/ABC/ACPM/ADA/AGS /APhA/ASPC/NLA/PCNA Guideline on the Management of Blood Cholesterol: executive summary: a Report of the American College of Cardiology/American Heart Association Task Force on Clinical Practice Guidelines. J Am Coll Cardiol. (2018). doi: 10.1016/j.jacc.2018.11.002. [Epub ahead of print].

74. Ferdowsian HR, Barnard ND. Effects of plant-based diets on plasma lipids. Am J Cardiol. (2009) 104:947-56. doi: 10.1016/j.amjcard.2009.05.032

75. Wang F, Zheng J, Yang B, Jiang J, Fu Y, Li D. Effects of vegetarian diets on blood lipids: a systematic review and meta-analysis of randomized controlled trials. J Am Heart Assoc. (2015) 4:e002408. doi: 10.1161/jaha.115.002408

76. Pischke CR, Weidner G, Elliott-Eller M, Ornish D. Lifestyle changes and clinical profile in coronary heart disease patients with an ejection fraction of $<$ or $=40 \%$ or $>40 \%$ in the Multicenter Lifestyle Demonstration Project. Eur J Heart Fail. (2007) 9:928-34. doi: 10.1016/j.ejheart.2007.05.009

77. Choi EY, Allen K, Mcdonnough M, Massera D, Ostfeld RJ. A plant-based diet and heart failure: case report and literature review. J Geriatr Cardiol. (2017) 14:375-8. doi: 10.11909/j.issn.1671-5411.2017.05.003

78. Yokoyama Y, Levin SM, Barnard ND. Association between plant-based diets and plasma lipids: a systematic review and meta-analysis. Nutr Rev. (2017) 75:683-98. doi: 10.1093/nutrit/nux030

79. Esterbauer H, Gebicki J, Puhl H, Jurgens G. The role of lipid peroxidation and antioxidants in oxidative modification of LDL. Free Radic Biol Med. (1992) 13:341-90.

80. Vinson JA, Dabbagh YA, Serry MM, Jang J. Plant flavonoids, especially tea flavonols, are powerful antioxidants using an in vitro oxidation model for heart disease. J Agric Food Chem. (1995) 43:2800-2. doi: 10.1021/jf00059a005

81. Tuso P, Stoll SR, Li WW. A plant-based diet, atherogenesis, and coronary artery disease prevention. Perm J. (2015) 19:62-7. doi: 10.7812/TPP/14-036 
82. Chin JH, Azhar S, Hoffman BB. Inactivation of endothelial derived relaxing factor by oxidized lipoproteins. J Clin Invest. (1992) 89:10-8. doi: 10.1172/JCI115549

83. Witztum JL. The oxidation hypothesis of atherosclerosis. Lancet. (1994) 344:793-5.

84. Singh K, Rohatgi A. Examining the paradox of high high-density lipoprotein and elevated cardiovascular risk. J Thorac Dis. (2018) 10:109-12. doi: $10.21037 /$ jtd.2017.12.97

85. Roberts CK, Barnard RJ. Effects of exercise and diet on chronic disease. J Appl Physiol. (2005) 98:3-30. doi: 10.1152/japplphysiol.00852.2004

86. Holligan SD, West SG, Gebauer SK, Kay CD, Kris-Etherton PM. A moderatefat diet containing pistachios improves emerging markers of cardiometabolic syndrome in healthy adults with elevated LDL levels. Br J Nutr. (2014) 112:744-52. doi: 10.1017/s0007114514001561

87. Berryman CE, Fleming JA, Kris-Etherton PM. Inclusion of almonds in a cholesterol-lowering diet improves plasma HDL subspecies and cholesterol efflux to serum in normal-weight individuals with elevated LDL cholesterol. J Nutr. (2017) 147:1517-23. doi: 10.3945/jn.116. 245126

88. Kenchaiah S, Evans JC, Levy D, Wilson PW, Benjamin EJ, Larson MG, et al. Obesity and the risk of heart failure. N Engl J Med. (2002) 347:305-13. doi: 10.1056/NEJMoa020245

89. Fliotsos M, Zhao D, Rao VN, Ndumele CE, Guallar E, Burke GL, et al. Body mass index from early-, mid-, and older-adulthood and risk of heart failure and atherosclerotic cardiovascular disease: MESA. J Am Heart Assoc. (2018) 7:e009599. doi: 10.1161/JAHA.118.009599

90. Lauer MS, Anderson KM, Kannel WB, Levy D. The impact of obesity on left ventricular mass and geometry. The Framingham Heart Study. JAMA. (1991) 266:231-6

91. Kasai T, Bradley TD. Obstructive sleep apnea and heart failure: pathophysiologic and therapeutic implications. J Am Coll Cardiol. (2011) 57:119-27. doi: 10.1016/j.jacc.2010.08.627

92. Klop B, Elte JWF, Cabezas MC. Dyslipidemia in obesity: mechanisms and potential targets. Nutrients. (2013) 5:1218-40. doi: 10.3390/nu5041218

93. Benjamin EJ, Blaha MJ, Chiuve SE, Cushman M, Das SR, Deo $\mathrm{R}$, et al. Heart disease and stroke statistics--2017 update: a report from the American Heart Association. Circulation. (2017) 135:e146-603. doi: 10.1161/cir.0000000000000485

94. Turner-Mcgrievy GM, Davidson CR, Wingard EE, Wilcox S, Frongillo EA. Comparative effectiveness of plant-based diets for weight loss: a randomized controlled trial of five different diets. Nutrition. (2015) 31:350-8. doi: 10.1016/j.nut.2014.09.002

95. Huang RY, Huang CC, Hu FB, Chavarro JE. Vegetarian diets and weight reduction: a meta-analysis of randomized controlled trials. J Gen Intern Med. (2016) 31:109-16. doi: 10.1007/s11606-015-3390-7

96. He K, Hu FB, Colditz GA, Manson JE, Willett WC, Liu S. Changes in intake of fruits and vegetables in relation to risk of obesity and weight gain among middle-aged women. Int J Obes Relat Metab Disord. (2004) 28:1569-74. doi: $10.1038 /$ sj.ijo.0802795

97. Spencer EA, Appleby PN, Davey GK, Key TJ. Diet and body mass index in 38000 EPIC-Oxford meat-eaters, fish-eaters, vegetarians and vegans. Int J Obes Relat Metab Disord. (2003) 27:728-34. doi: 10.1038/sj.ijo. 0802300

98. Tonstad S, Butler T, Yan R, Fraser GE. Type of vegetarian diet, body weight, and prevalence of type 2 diabetes. Diabetes Care. (2009) 32:791-6. doi: $10.2337 / \mathrm{dc} 08-1886$

99. Vergnaud AC, Norat T, Romaguera D, Mouw T, May AM, Travier N, et al. Meat consumption and prospective weight change in participants of the EPIC-PANACEA study. Am J Clin Nutr. (2010) 92:398-407. doi: 10.3945/ajcn.2009.28713

100. Kahleova H, Levin S, Barnard N. Cardio-metabolic benefits of plant-based diets. Nutrients. (2017) 9:848. doi: 10.3390/nu9080848

101. Rosano GM, Vitale C, Seferovic P. Heart failure in patients with diabetes mellitus. CFR. (2017) 3:52-5. doi: 10.15420/cfr.2016:20:2

102. Lind M, Olsson M, Rosengren A, Svensson AM, Bounias I, Gudbjornsdottir $\mathrm{S}$. The relationship between glycaemic control and heart failure in 83,021 patients with type 2 diabetes. Diabetologia. (2012) 55:2946-53. doi: $10.1007 / \mathrm{s} 00125-012-2681-3$
103. Ingelsson E, Sundström J, Ärnlöv J, Zethelius B, Lind L. Insulin resistance and risk of congestive heart failure. JAMA. (2005) 294:334-41. doi: 10.1001/jama.294.3.334

104. Satija A, Bhupathiraju SN, Rimm EB, Spiegelman D, Chiuve SE, Borgi L, et al. Plant-based dietary patterns and incidence of type 2 diabetes in us men and women: results from three prospective cohort studies. PLoS Med. (2016) 13:e1002039. doi: 10.1371/journal.pmed.1002039

105. Chen Z, Zuurmond MG, Van Der Schaft N, Nano J, Wijnhoven HAH, Ikram MA, et al. Plant versus animal based diets and insulin resistance, prediabetes and type 2 diabetes: the Rotterdam Study. Eur J Epidemiol. (2018) 33:883-93. doi: 10.1007/s10654-018-0414-8

106. Barnard ND, Cohen J, Jenkins DJ, Turner-Mcgrievy G, Gloede L, Jaster B, et al. A low-fat vegan diet improves glycemic control and cardiovascular risk factors in a randomized clinical trial in individuals with type 2 diabetes. Diabetes Care. (2006) 29:1777-83. doi: 10.2337/dc06-0606

107. Barnard ND, Cohen J, Jenkins DJ, Turner-Mcgrievy G, Gloede L, Green A, et al. A low-fat vegan diet and a conventional diabetes diet in the treatment of type 2 diabetes: a randomized, controlled, 74-wk clinical trial. Am J Clin Nutr. (2009) 89:1588s-96s. doi: 10.3945/ajcn.2009.26736H

108. Anderson JW, Ward K. High-carbohydrate, high-fiber diets for insulintreated men with diabetes mellitus. Am J Clin Nutr. (1979) 32:2312-21.

109. Agrawal NK, Kant S. Targeting inflammation in diabetes: newer therapeutic options. World J Diabetes. (2014) 5:697-710. doi: 10.4239/wjd.v5.i5.697

110. Kahleova H, Tura A, Hill M, Holubkov R, Barnard ND. A plant-based dietary intervention improves beta-cell function and insulin resistance in overweight adults: a 16-week randomized clinical trial. Nutrients. (2018) 10:E189. doi: 10.3390/nu10020189

111. Lichtenstein AH, Schwab US. Relationship of dietary fat to glucose metabolism. Atherosclerosis. (2000) 150:227-43. doi: 10.1016/S0021-9150(99)00504-3

112. Kraegen EW, Cooney GJ. Free fatty acids and skeletal muscle insulin resistance. Curr Opin Lipidol. (2008) 19:235-41. doi: 10.1097/01.mol.0000319118.44995.9a

113. Sharma K, Kass DA. Heart failure with preserved ejection fraction: mechanisms, clinical features, and therapies. Circulation. (2014) 115:79-96. doi: 10.1161/CIRCRESAHA.115.302922

114. Kobayashi J, Ohtake K, Uchida H. NO-rich diet for lifestyle-related diseases. Nutrients. (2015) 7:4911-37. doi: 10.3390/nu7064911

115. Hummel SL, Seymour EM, Brook RD, Kolias TJ, Sheth SS, Rosenblum HR, et al. Low-sodium dietary approaches to stop hypertension diet reduces blood pressure, arterial stiffness, and oxidative stress in hypertensive heart failure with preserved ejection fraction. Hypertension. (2012) 60:1200-6. doi: 10.1161/hypertensionaha.112.202705

116. Moe SM, Zidehsarai MP, Chambers MA, Jackman LA, Radcliffe JS, Trevino LL, et al. Vegetarian compared with meat dietary protein source and phosphorus homeostasis in chronic kidney disease. Clin J Am Soc Nephrol. (2011) 6:257-64. doi: 10.2215/cjn.05040610

117. Chiu THT, Huang H-Y, Chiu Y-F, Pan W-H, Kao H-Y, Chiu JPC, et al. Taiwanese vegetarians and omnivores: dietary composition, prevalence of diabetes and IFG. PLoS ONE. (2014) 9:e88547. doi: 10.1371/journal.pone.0088547

118. Chauveau P, Koppe L, Combe C, Lasseur C, Trolonge S, Aparicio M. Vegetarian diets and chronic kidney disease. Nephrol Dial Transplant. (2019) 34:199-207. doi: 10.1093/ndt/gfy164

\section{Conflict of Interest Statement: RO consulted for Better Therapeutics.}

The remaining authors declare that the research was conducted in the absence of any commercial or financial relationships that could be construed as a potential conflict of interest.

Copyright (c) 2019 Allen, Gumber and Ostfeld. This is an open-access article distributed under the terms of the Creative Commons Attribution License (CC BY). The use, distribution or reproduction in other forums is permitted, provided the original author(s) and the copyright owner(s) are credited and that the original publication in this journal is cited, in accordance with accepted academic practice. No use, distribution or reproduction is permitted which does not comply with these terms. 